\title{
The effect of digestate and mineral fertilisation of cocksfoot grass on greenhouse gas emissions in a cocksfoot- based biogas production system
}

Vita Tilvikiene ${ }^{1 *} \mathbb{D}$, Kestutis Venslauskas ${ }^{2}$, Virmantas Povilaitis ${ }^{1}$, Kestutis Navickas ${ }^{2}$, Vidmantas Zuperka ${ }^{2}$ and Zydre Kadziuliene ${ }^{1}$

Abstract: Background: Climate mitigation is a major consideration when choosing bioenergy systems. Anaerobic digestion of biomass is a bioenergy system, which is normally used for the treatment of manure or other residues, but cultivated energy crops may also provide a potential feedstock. One of the main crops for biogas production is still maize, but it may be desirable to replace it by perennial grasses, which also have high yields, but do not require as much management. The aim of this study was to analyse greenhouse gas (GHG) emissions in a biogas production system based on a perennial grass, cocksfoot, grown under different fertiliser application systems.

Methods: Field and laboratory experiments were carried out over a 7-year period to evaluate the influence of mineral nitrogen and digestate fertiliser application on cocksfoot biomass and biogas productivity. The obtained data were used to calculate GHG emissions and emission savings for the whole biogas production cycle, by use of the SimaPro v.8 software with the IMPACT 2002+ model, based on the climate change environmental impact category.

Results: Productivity of cocksfoot (Dactylis glomerata L.) was influenced by the annual rate of nitrogen applied as fertiliser, the fertiliser type and year, as influenced by the weather conditions. The biomass yield of cocksfoot fertilised with $180 \mathrm{~kg}$ nitrogen $\mathrm{ha}^{-1}$ year $^{-1}$ was similar regardless if the nitrogen was applied as digestate or mineral fertiliser. At higher rates of nitrogen application (360-450 $\mathrm{kg} \mathrm{ha}^{-1}$ year ${ }^{-1}$ ), higher yields and lower net GHG emissions could be obtained from the biogas production cycle when the nitrogen was applied as digestate compared to mineral fertiliser, especially in dry years. Energy input over the whole cycle was mainly influenced by the type of fertiliser and the biomass yield. Mineral fertiliser generally caused higher levels of GHG emissions than organic digestate fertiliser, when the same amount of energy is produced.

Conclusions: The cocksfoot grass-based biogas production system showed that a significant GHG emission saving potential exists, if nitrogen is added as digestate instead of mineral fertiliser, for similar yields of biomass and energy from biogas. Cocksfoot grass fertilised with digestate is thus a promising feedstock for biogas production.

Keywords: Biogas, Energy crops, Productivity, Energy potential, GHG emission savings

\footnotetext{
* Correspondence: vita.tilvikiene@lammc.lt

${ }^{1}$ Lithuanian Research Centre for Agriculture and Forestry, Instituto al. 1,

Akademija, LT-58344 Kèdainiai, Lithuania

Full list of author information is available at the end of the article
}

(c) The Author(s). 2020 Open Access This article is distributed under the terms of the Creative Commons Attribution 4.0 International License (http://creativecommons.org/licenses/by/4.0/), which permits unrestricted use, distribution, and reproduction in any medium, provided you give appropriate credit to the original author(s) and the source, provide a link to the Creative Commons license, and indicate if changes were made. 


\section{Background}

The importance of the renewable energy sector has been recognized worldwide. Increased use of such energy sources is playing a significant role in climate change mitigation strategies, as well as in the improvement of economic factors (contribution to regional and national economies), and to energy cost savings and social conditions (especially increased employment). Such benefits may be enhanced by increasing the effectiveness of biomass conversion [1-5]. Many countries have traditionally used forest biomass for energy and much research is currently under way to assess the impacts of forest bioenergy practices on sustainability parameters [6-9]. However, increasing attention is also being paid to the agricultural sector and the use of agriculture-derived biomass for generation of bioenergy $[10,11]$. The use of alternative feedstocks for bioenergy and the resulting reduction in greenhouse gas (GHG) emissions is being analysed widely [12-14]. It is assessed that by 2050, the global bioenergy potential from agricultural land will range from 64 to 161 EJ year ${ }^{-1}$ but it will be strongly influenced by the development in the global demand for food and animal feed [15]. The increasing demand for biomass raw materials and the large biomass production potential in agriculture is encouraging detailed sector analysis as a basis for making key decisions on future energy pathways.

Agricultural management differs considerably between regions in the world, due to the variation, for example, in climate conditions, management technologies, and the length of the growing season. At present, there is a paucity of evidence on sustainability of agricultural biomass use for bioenergy in Northern European countries, but this pathway could be a meaningful part of a circular bioeconomy. However, the success of the bioeconomy, and especially the circular bioeconomy, will depend on the achievement of environmental, social, and economic benefits [16]. This will require new approaches and improvements in efficiency throughout the agricultural production cycle. Agriculture is the second highest global GHG emitter after the combustion of fossil fuels for energy production, but it is expected that with new high-precision management technologies and innovative products, the sector will be able to contribute to climate change mitigation [17].

It is also important to ensure a diverse primary energy production, so that it includes more, and more local, renewable energy sources. One such locally based renewable energy source is biogas. Different political and technological conditions have influenced the development of the biogas sector in different countries [18], but in many countries, the biogas production potential, though high, is not yet fully utilized [19]. Biogas, as a renewable fuel, is flexible and can be used in heat and electricity production or as a transportation fuel.
In order to expand the supply of raw materials for biogas production, annual and perennial crops are currently being used to produce biogas. The mono-digestion of perennial grasses seems to be promising for the generation of biogas [20], although co-digestion of perennial grasses with manure might even more effective [19]. Perennial grasses have advantages over annual crops as a feedstock, because they are able to produce stable, high yields of dry matter under different environmental conditions and do not compete with food production for raw materials [21, 22]. Grasses are also important in agriculture for soil preservation and improvement of biodiversity. Perennial grasses in most environmentally protected areas have to be cut at least once a year [23]. Such biomass could be collected and used for biogas production. Changing land use from wheat production, which is a very important crop in Lithuania, to grassland for a few years could improve the soil fertility and structure, which might help to increase future grain yields.

Biogas production from anaerobic biomass digestion technologies can be assessed in terms of its positive environmental impact, as anaerobic digestion kills weed seeds and pathogens in manure before it is applied as digestate to the fields [24-26]. Moreover, the residue from biogas production, i.e., the digestate, can replace mineral fertilisers in what can be termed a biomassbiogas-biomass cycle [27-29] (Fig. 1). The present study estimated the GHG emissions of such a biogas production cycle, in which a perennial grass, cocksfoot (Dactylis glomerata L.), was grown as a biogas feedstock, with digestate from its co-digestion with manure being used

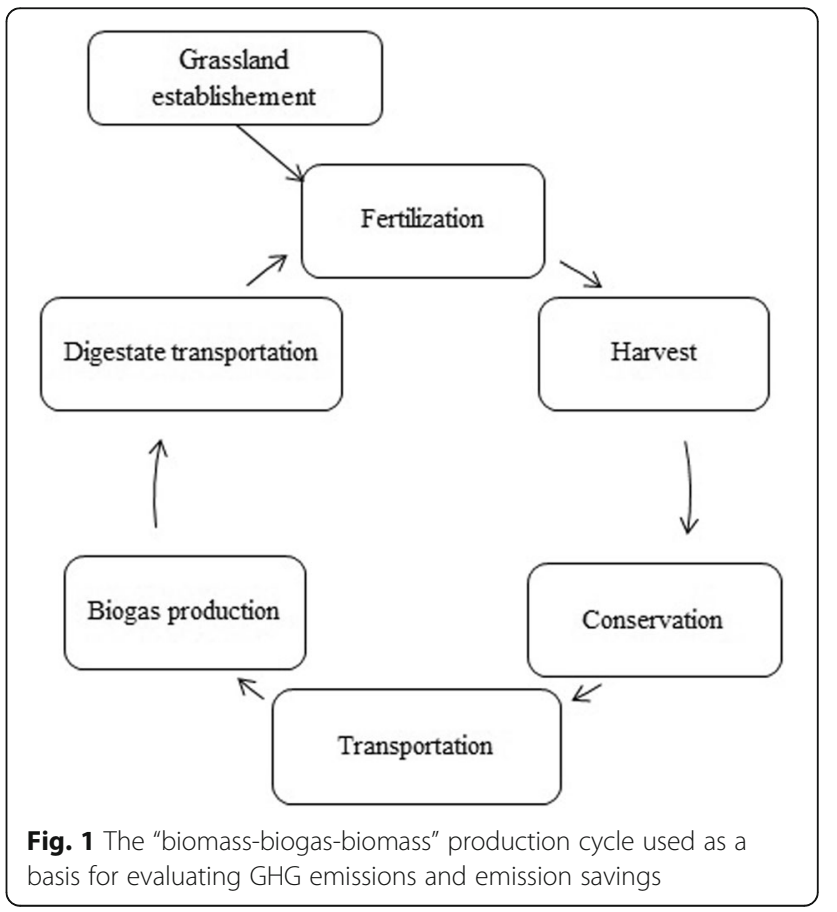


for fertilisation. The comparison of GHG emissions was made between scenarios using different fertiliser application systems for cocksfoot production. The cocksfoot grass was established in the first year of the study, while yields were evaluated in the subsequent six annual growing cycles.

It has been found that the energy potential per hectare when using crops for anaerobic digestion is limited by the level of yields [15]. The productivity of crops depends on climate, soil and cultivation technology, annual growing cycle, and the number of harvests per year. Energy conversion efficiency has also been found to be important. Compared to the energy input, perennial grasses produce a larger amount of total energy than annual crops, because they require less energy consumption for management. More intensive cultivation, for example fertiliser application and genetic modification, can increase crop productivity by up to ten times compared to non-intensive crop production $[22,30]$. A trade-off must thus be made between the energy input and output. It should be noted that perennial crops can be grown and be productive in one place for more than 10 years. Therefore, a broad approach is needed to assess the environmental benefit of agricultural management systems with longer rotations and biogas production.

This publication is part of the national research project "Biomass for Biogas." The aim of the project was to evaluate the possibilities and profitability of the use of perennial grasses for biogas production. Two experiments were established for the project. The data from the first experiment, related to the production and digestion of three different grasses, have been published [3133]. The second experiment was laid out to evaluate the effectiveness of cocksfoot fertilisation with digestate and nitrogen mineral fertiliser in a biomass-biogas-biomass system. The effect of digestate fertilisation on biomass quality is presented by Tilvikiene et al. [34], while the aim of the work reported here was to analyse and compare the GHG emissions from the circular biomassbiogas-biomass production system based on cocksfoot grass, grown under different fertiliser application systems, for mono-feedstock production of biogas.

\section{Materials and methods}

The study has two parts: first the field and laboratory experiments and, second, the calculations (modelling) of GHG emissions and emission savings. Data from the field experiments (biomass productivity) and laboratory experiments (biogas productivity and energy value) were integrated in a life-cycle analysis (LCA). The field and laboratory experiments were planned to obtain more precise information about GHG emissions in near-operational conditions.

\section{Field experiment}

The field experiment was established with cocksfoot grass (Dactylis glomerata) in central Lithuania (55 $23^{\prime}$ $50^{\prime \prime} \mathrm{N}, 23^{\circ} 51^{\prime} 40^{\prime \prime}$ E) on an Endocalcari-Epihypogleyic Cambisol (CMg-p-wcan) soil [35] in 2009. Eight different fertiliser treatments were applied to the cocksfoot sward: control (unfertilised), nitrogen $(\mathrm{N})$ application with mineral fertiliser (180 and $360 \mathrm{~N} \mathrm{~kg} \mathrm{ha}^{-1}$ year $^{-1}$ ) and $\mathrm{N}$ application with digestate $(\mathrm{N}$ application rates with the added digestate were 90, 180, 270, 360, and $450 \mathrm{~kg} \mathrm{~N}$ $\mathrm{ha}^{-1}$ year $\left.^{-1}\right)$. Experimental plots were $3 \times 5 \mathrm{~m}\left(15 \mathrm{~m}^{2}\right)$ arranged in randomised block design with four replicates. Small-plot machinery, Hege-212, was used for the harvesting. Fertilisers were applied manually.

Cultivation input in the year of establishment included ploughing, soil cultivation, sowing, fertilisation and cutting three times. At the year of establishment, perennial grasses do not require much fertiliser, and therefore only one-third of the annual rate of fertilisers was applied at the cocksfoot germination stage. In subsequent years, fertilisers (mineral or digestate) were applied twice a year, with half the planned annual application rate being applied each time. The first fertiliser application was made in the spring at the beginning of the growing season, and the second was made after the first cut of the sward. The sward was cut three times each growing season: first at the heading stage, second after regrowth at the end of July and third after regrowth at the beginning of October.

The digestate from a working plant using pig manure and agro-biomass for the digestion was selected for the experiment. The chemical composition of the digestate varies greatly over the year, so the $\mathrm{N}$ concentration and content were measured and calculated before each application (Table 1). The chemical composition of the digestate has been previously published [34].

\section{Weather conditions}

The weather conditions varied throughout the time of the experiment (Table 2). The most stressful situation for plants was in 2015 when the droughts started in June and lasted until the late autumn. In that year, the average rainfall in July was only $57 \mathrm{~mm}$, with all the rain falling in only 3 days.

\section{Biogas production in the laboratory}

Anaerobic digestion experiments, for which experimental design and methodology is described more fully elsewhere [28], were carried out using cocksfoot grass silage. The grass silage from each year was prepared from fresh grass samples chopped to a particle size of $3-5 \mathrm{~cm}$. For ensiling, no preservatives were used. The chopped samples were ensiled in 31 glass jars and sealed. The silage was kept for 70 days at $14-18{ }^{\circ} \mathrm{C}$ before samples were 
Table 1 Amount of mineral fertiliser and digestate spread on the fields for each of eight fertilisation scenarios (SC) (see further details in the section "Evaluation scenarios"). Note, only one-third of the annual fertiliser rate was applied in the establishment year 2009 due to low nutrient demand of the germinating seeds

\begin{tabular}{|c|c|c|c|c|c|c|c|c|}
\hline \multirow{2}{*}{$\begin{array}{l}\text { Scenario } \\
\mathrm{N} \text { application rate }\left(\mathrm{kg} \mathrm{ha}^{-1}\right)\end{array}$} & \multicolumn{3}{|c|}{ Mineral $\mathrm{N}$ fertiliser $\left(\mathrm{kg} \mathrm{ha}^{-1}\right)$} & \multicolumn{5}{|c|}{ Digestate $\left(\mathrm{t} \mathrm{ha}^{-1}\right.$ ) } \\
\hline & $\overline{\mathrm{SC} 1}$ & $\mathrm{SC2}$ & $\mathrm{SC} 3$ & $\overline{S C 4}$ & SC5 & SC6 & SC7 & $\mathrm{SC} 8$ \\
\hline Year & 0 & 180 & 360 & 90 & 180 & 270 & 360 & 450 \\
\hline 2009 & 0 & 176.5 & 352.9 & 4.26 & 8.52 & 12.78 & 17.05 & 21.31 \\
\hline 2010 & 0 & 529.4 & 1058.8 & 12.95 & 25.89 & 38.85 & 51.80 & 64.75 \\
\hline 2011 & 0 & 529.4 & 1058.8 & 23.68 & 47.37 & 71.05 & 94.74 & 118.42 \\
\hline 2012 & 0 & 529.4 & 1058.8 & 15.79 & 31.58 & 47.37 & 63.16 & 78.95 \\
\hline 2013 & 0 & 529.4 & 1058.8 & 16.45 & 32.91 & 49.36 & 65.81 & 82.27 \\
\hline 2014 & 0 & 529.4 & 1058.8 & 19.15 & 38.30 & 57.45 & 76.60 & 95.75 \\
\hline 2015 & 0 & 529.4 & 1058.8 & 31.03 & 62.07 & 93.10 & 124.14 & 155.17 \\
\hline
\end{tabular}

removed to assess the quality of the silage and determine its chemical composition. Prepared 150 g samples were placed into an inoculum of anaerobically digested material from the biogas digester of a piggery farm. After an acclimation period of 50-60 days, an anaerobic digestion experiment was started using batch mode to determine the methane production potential of the biomass. The experiments were conducted using laboratory-scale (20 l) anaerobic cylindrical continuous operation biogas digesters in an experimental design with three replications. The digester was maintained in a mesophilic environment at $38 \pm 1{ }^{\circ} \mathrm{C}$ temperature and volumetric organic loading rate of $2 \mathrm{~kg} \mathrm{~m}^{3}$ day $^{-1}$. The biogas produced in each digester was collected at the top and vented through a drum-type biogas flowmeter to a gasholder (Tedlar bag). The biogas collected was analysed using an Awite Bioenergie GmbH AwiFlex analyser. The total biogas energy potential was calculated by the multiplication of biomass dry matter yield and biomethane yield.

\section{Statistical analysis}

One-way analysis of variance was used for the statistical analysis of biogas productivity and biomethane yield, and two-way analysis of variance for the crop productivity using the SAS 9.4 software [36]. Pairwise differences were tested with a Tukey's studentized range test in the MEANS statement. Statistical inferences were made at the 0.05 significance level.

\section{Assessment of GHG emissions and emission savings}

An environmental impact assessment enables a meaningful comparison of the impact on the environment of the processes involved in different designs of the biomass-biogas-biomass production cycle (scenarios), both separate processes and in combination. Assessment of sustainability indicators starts with the cultivation and harvesting of the raw material and ends with the consumption of biogas for power generation and spreading of the digestate on the field. The environmental impact assessment of the whole biogas production cycle using cocksfoot grass was carried out in accordance with ISO14040 and ISO14044 standards. The IMPACT 2002+ model was used for the assessment together with SimaPro v.8 software [37, 38], focussing on the climate change environmental impact category over a 100-year period, with life-cycle GHG emissions $\left(\mathrm{CO}_{2}\right.$-eq) as the modelling output [39].

Table 2 Average monthly air temperature and rainfall during the vegetation period during the years of the experiment

\begin{tabular}{|c|c|c|c|c|c|c|c|c|c|c|c|c|c|c|}
\hline \multirow{2}{*}{$\begin{array}{l}\text { Month } \\
\text { Year }\end{array}$} & \multicolumn{7}{|c|}{ Air temperature, ${ }^{\circ} \mathrm{C}$} & \multicolumn{7}{|c|}{ Rainfall, mm month ${ }^{-1}$} \\
\hline & 04 & 05 & 06 & 07 & 08 & 09 & 10 & 04 & 05 & 06 & 07 & 08 & 09 & 10 \\
\hline 2009 & 8.8 & 12.7 & 14.6 & 18.1 & 16.8 & 13.9 & 5.2 & 13 & 27 & 169 & 90 & 67 & 48 & 95 \\
\hline 2010 & 7.3 & 13.7 & 16.2 & 21.7 & 19.9 & 11.9 & 5.0 & 44 & 95 & 72 & 142 & 71 & 52 & 38 \\
\hline 2011 & 8.8 & 12.9 & 18.1 & 19.7 & 17.4 & 13.7 & 7.6 & 16 & 47 & 44 & 115 & 115 & 54 & 23 \\
\hline 2012 & 7.3 & 13.3 & 14.9 & 18.8 & 16.6 & 13.2 & 7.3 & 47 & 38 & 79 & 121 & 82 & 43 & 62 \\
\hline 2013 & 4.7 & 16.0 & 18.6 & 18.5 & 18.1 & 12.6 & 8.5 & 46 & 49 & 47 & 104 & 42 & 78 & 28 \\
\hline 2014 & 8.9 & 13.0 & 14.4 & 20.0 & 17.7 & 13.3 & 7.3 & 27 & 76 & 65 & 69 & 111 & 22 & 39 \\
\hline 2015 & 7.0 & 11.4 & 15.1 & 17.1 & 19.7 & 14.0 & 5.2 & 52 & 50 & 26 & 57 & 6 & 66 & 7 \\
\hline
\end{tabular}




\section{Evaluation scenarios}

Eight scenarios were created for the assessment of lifecycle GHG emissions under the environmental impact assessment framework. They varied by fertiliser type and $\mathrm{N}$ application rate (Table 1).

\section{Scope of system}

The scope of the assessment covered the whole cycle of cocksfoot grass biomass production and processing into energy under the different scenarios involving different rates and types of fertiliser application to the grass. It included the emission of pollutants and consumption of resources throughout the whole cycle of the biomass-biogas-biomass system, which was thus considered to be a complete and closed cycle of technological operations, as in the environmental evaluation of Nekrošius et al. (Fig. 2) [33].

The assessment was performed for each of 7 years (2009-2015) of growing the cocksfoot grass. Total energy inputs in biogas production from the grass were assessed for plant cultivation (soil preparation and other cultivation activities, fertilisation, harvesting, transportation, and ensiling), processing into biogas, and digestate distribution back to the field as a fertiliser. Direct and indirect energy consumption were both included as suggested in the literature [38, 40, 41]. Direct energy inputs were, typically, diesel fuel and electricity used directly in the production cycle. Indirect energy input included energy used for seed and mineral fertiliser production, production and maintenance of machinery and equipment, and embodied energy in buildings [42]. The boundaries of the system included all material and energy inputs as well as GHG emissions.

For energy inputs associated with grassland production, the first year of grass establishment was distinguished from the succeeding years of grass growth. Multiple components of the complex biomass-biogas-biomass system were considered in the assessment (Table 3).

The modelled system

The cocksfoot grass field was shallow-ploughed and the soil was then loosened by a cultivator. The cocksfoot was sown at a density of $18 \mathrm{~kg} \mathrm{ha}^{-1}$ using a $3 \mathrm{~m}$ working width seeder. The equipment's arrival and departure from the field, fuelling (delivery to the field) and

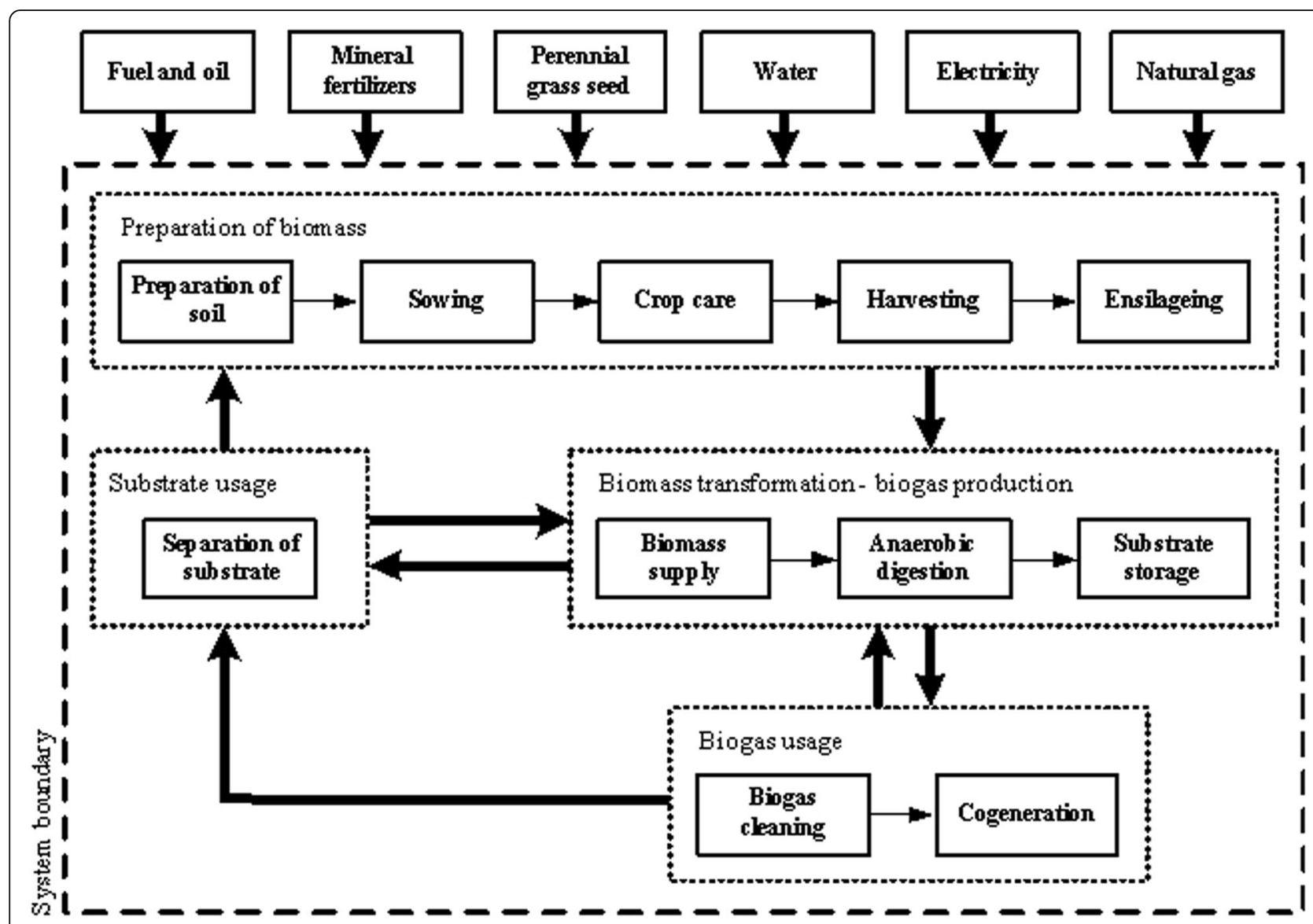

Fig. 2 Flow scheme of the biogas production cycle biomass-biogas-biomass of Nekrošius et al. [33], which was used for the purpose of this study 
Table 3 Components of energy inputs in calculation of GHG emissions for cocksfoot grass production and processing into biogas in seven annual growing cycles

\begin{tabular}{lllll}
\hline Only in year 1 of grass growth & & & For all 1-7 years of grass growth & \\
\cline { 1 - 2 } $\begin{array}{llll}\text { Direct energy input with } \\
\text { subsequent direct GHG emissions }\end{array}$ & $\begin{array}{l}\text { Indirect energy input with } \\
\text { subsequent indirect GHG emissions }\end{array}$ & $\begin{array}{l}\text { Direct energy input with } \\
\text { subsequent direct GHG emissions }\end{array}$ & $\begin{array}{l}\text { Indirect energy input with } \\
\text { subsequent indirect GHG emissions }\end{array}$ \\
\hline Soil tillage & Agricultural machinery & Cutting & Agricultural machinery \\
Soil cultivation & Fertilisers & Raking & Fertilisers \\
Sowing & Seeds & Chopping and collection & Human work \\
Fertilisation & Human work & & Transportation & Ensiling \\
Cutting & & Anaerobic digestion & \\
& & Spreading of digestate & \\
\hline
\end{tabular}

turnaround at the headland (strip of land left unploughed at the edge of the field) were included in the calculations. The distance from the field to the farm (site of equipment storage, digestate storage and ensiling) was assumed to be $3.0 \mathrm{~km}$. The cocksfoot grass biomass was harvested with a chopper and tedded with a $5.5 \mathrm{~m}$ rotary tedder. Biomass was transported from the field by a tractor with an $8 \mathrm{t}$ capacity trailer to the site where it was later ensiled in trenches, being spread evenly and compressed to the average on-farm ensiling density of 200 $\mathrm{kg} \mathrm{m}^{-3}$ dry matter [12]. During cutting, transport and ensiling, the grass wilted naturally, and it was assumed that the biomass losses did not exceed $2 \%$ of the total biomass produced [13]. The ensiling process took place without the presence of organic acids or the use of chemical preservatives. The quality and flavour of the silage were not considered, because it was intended for production of biogas. Later, the silage was transported by tractor with a front-end loader to the stationary biomass mixing and dosing device $\left(5 \mathrm{~m}^{3}\right)$, which mixed it with the liquid fraction. The silage was delivered by a screw conveyor to the anaerobic digester.

For the modelling, it was furthermore assumed that anaerobic digestion of the cocksfoot grass as monofeedstock was carried out in a cylindrical steel, continuous operation, biogas digester. The digester was maintained in a mesophilic environment at a temperature of $38{ }^{\circ} \mathrm{C}$ and volumetric organic loading rate of $2 \mathrm{~kg} \mathrm{~m}^{-3}$ day $^{-1}$. Water was used in order to maintain a steady dry matter concentration of $14-17 \%$ in the feedstock. The increase in the quantity of digestate due to dilution was taken into account. The loss of biogas in the production process varies from 0.3 to $1.5 \%$ of the total amount of biogas produced [2-4], and a loss of $0.5 \%$ was used in the calculations. Our earlier studies showed that biogas produced from cocksfoot grass usually contains 58.861.3\% methane [33] [43], while the rest is $\mathrm{CO}_{2}$, which, as biogenic emission, was assumed to have net emissions and a net global warming potential of 0 . The extracted biogas was cleaned of impurities, compressed and supplied to the cogeneration unit where it was burned in an internal combustion engine driving a $500 \mathrm{~kW}$ e generator of $36.1 \%$ electrical and $46.5 \%$ thermal efficiency. The biogas plant was in operation $8760 \mathrm{~h}_{\text {year }}{ }^{-1}$ with an annual demand of 1.77 million $\mathrm{m}^{3}$ of biogas, with an energy content of $22.55 \mathrm{MJ} \mathrm{m}^{-3}$. The electricity generation of this biogas plant is our functional unit.

Biogas plant operation used $8 \%$ of the electricity produced and the remaining power was supplied to the power distribution network, thus replacing electricity which was assumed to be the average European electricity mix (Union for the Coordination of the Transmission of Electricity [44]), in agreement with the recommendations by Magiri-Skouloudi et al. [45]. Thermal energy produced by the engine cooling and exhaust systems was used to heat the feedstock and maintain the required temperature in the digester $(10 \%$ of produced heat). Excess thermal energy was supplied to other consumers. As the output of electricity was identical for all scenarios and years, it was assumed that the excess heat provided to consumers was also constant, with no implications for the comparison among scenarios and years. A similar characterisation methodology for determining biogas plant power was applied by Bacenetti et al. [13]. The digested substrate was pumped into a storage reservoir and was later spread on the fields as fertiliser in accordance with scenarios 4 to 8 . The digestate applied to the soil emits indirect $\mathrm{N}_{2} \mathrm{O}$ of biogenic origin due to the release of $\mathrm{N}$ during periods when there is no uptake by the vegetation. Following Møller et al. [46], the indirect $\mathrm{N}_{2} \mathrm{O}$ emission from soil when applying digestate, converted to a global warming potential, was on average $46.5 \mathrm{~kg} \mathrm{CO} \mathrm{CO}_{2}$-eq $\mathrm{t}^{-1}$ digestate. The average indirect $\mathrm{N}_{2} \mathrm{O}$ emission factor used was $1.49 \%$ of the applied mineral $\mathrm{N}$, resulting in $2.32 \mathrm{~kg} \mathrm{CO}_{2}$-eq $\mathrm{kg}^{-1} \mathrm{~N}$ in the applied mineral fertiliser [47]. In this study, we defined direct $\mathrm{N}_{2} \mathrm{O}$ emissions as those derived directly from energy consumption, and indirect $\mathrm{N}_{2} \mathrm{O}$ emissions as those 
generated during the industrial $\mathrm{N}$ fertiliser production process and $\mathrm{N}_{2} \mathrm{O}$ emissions from soil when $\mathrm{N}$ fertiliser is being applied.

\section{Acquisition of input data}

Data on plant biomass preparation, transportation, biogas plant and equipment were taken from the ecoinvent v3 database [48], while the biomass yields and biogas productivity were taken from field trials and laboratory experiments, respectively.

\section{Ensuring comparability of the assessed scenarios}

A consistent supply of biogas must be assured, but the yields of perennial grass dry matter and biogas vary from year to year. Therefore, the land area required to obtain the quantity of biomass needed to produce 39917 GJ of energy to maintain a $500 \mathrm{~kW}_{\mathrm{e}}$ biogas plant was calculated by dividing the annual amount of required biogas by the methane potential and biomass yield. Biogas digester sizes and technological equipment vary, so energy input also varies. For this assessment, it was assumed that the biogas plant operates $8760 \mathrm{~h}_{\text {year }}{ }^{-1}$, and the cogenerator $8000 \mathrm{~h}$ year $^{-1}$. The lifetimes of the biogas plant, process equipment and agricultural machinery were estimated according to manufacturers and taken from ecoinvent database as well as the technical parameters and average fuel consumption of the agricultural equipment. In the modelling, it was assumed that one worker emits $0.52 \mathrm{~kg}$ of $\mathrm{CO}_{2}$ per hour based on household expenditures [49]. Results were adapted and normalised and are expressed as emissions of $\mathrm{CO}_{2}$-eq ha ${ }^{-1}$ as recommended by Bird et al. [50]. The substitution of electricity and heat from fossil fuels by biogas generated from cocksfoot grass was taken into consideration.

\section{Results}

\section{Biomass yield}

The productivity of cocksfoot varied significantly with fertiliser type $(p<0.05), \mathrm{N}$ dosage $(p<0.05)$ and year $(p$ $<0.01$ ). Biomass yields decreased with increasing $\mathrm{N}$ application rate for mineral fertiliser, but increased with increasing $\mathrm{N}$ application rate for digestate (Fig. 3, Table 3). In the sixth year, the most productive system was cocksfoot grass fertilised with digestate applied at a rate of $450 \mathrm{~kg} \mathrm{~N} \mathrm{ha}^{-1}$.

The biomass yield of swards fertilised with digestate applied at a rate of $180 \mathrm{~kg} \mathrm{~N} \mathrm{ha}^{-1}$ did not differ significantly in any year from fields with $\mathrm{N}$ applied as mineral fertiliser at the same rate, except 2012 and 2014 (Table 4). In 2011 the yield of cocksfoot fertilised with digestate was also higher compared to mineral $\mathrm{N}$ application, but the difference was not significant.

The differences in biomass yield could be explained by the different weather conditions, especially rainfall and temperature in spring. When the rainfall in April was lower and temperatures were higher than the multiannual average (in 2011 and 2014), the yield of cocksfoot fertilised with digestate was higher compared to cocksfoot fertilised with mineral N. But when the rainfall and temperature were higher than the multi-annual average

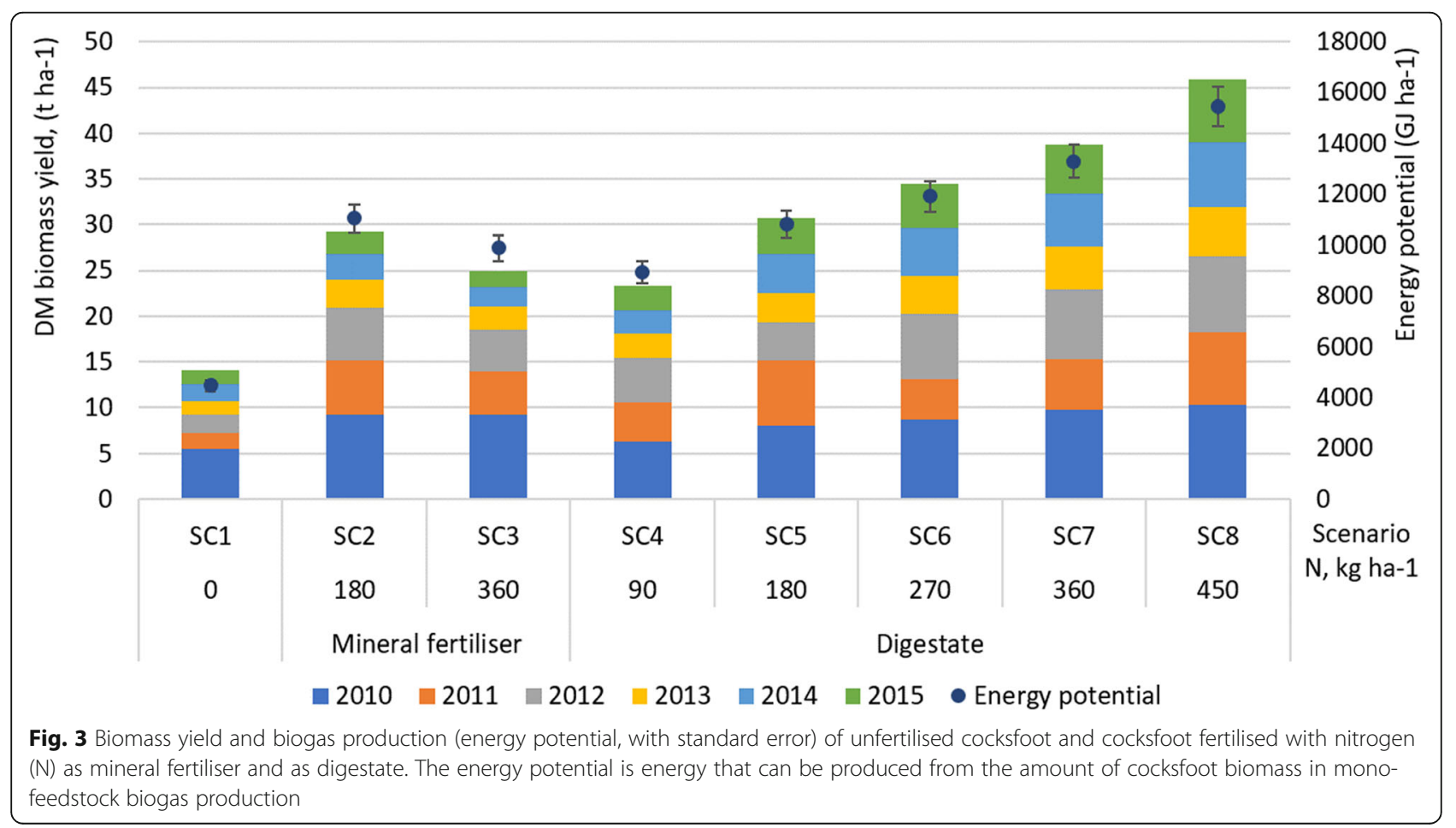


Table 4 Statistically significant differences between biomass yields of different fertiliser application treatments. Treatments within a specific year (annual growing cycle) are significantly different when no letters are the same $(a=0.05)$

\begin{tabular}{|c|c|c|c|c|c|c|c|c|}
\hline \multirow{2}{*}{$\begin{array}{l}\text { Fertiliser type } \\
\mathrm{N} \text { application rate }\left(\mathrm{kg} \mathrm{ha}{ }^{1} \text { year }{ }^{-1}\right)\end{array}$} & \multicolumn{3}{|c|}{ Mineral $N$ fertiliser } & \multicolumn{5}{|c|}{ Digestate } \\
\hline & $\overline{0}$ & 180 & 360 & 90 & 180 & 270 & 360 & 450 \\
\hline $\begin{array}{l}\text { Scenario } \\
\text { Year }\end{array}$ & SC1 & SC2 & SC3 & SC4 & SC5 & SC6 & $\mathrm{SC7}$ & SC8 \\
\hline 2010 & $a$ & bcde & bcde & $a$ & $b$ & $b c$ & cde & $\mathrm{e}$ \\
\hline 2011 & $a$ & $b c$ & $b$ & $b$ & $\mathrm{~cd}$ & def & $f$ & cdef \\
\hline 2012 & $a$ & $d$ & $b$ & c & $b$ & $b$ & $b$ & e \\
\hline 2013 & $\mathrm{a}$ & $b$ & $b$ & $b$ & $b$ & c & cde & e \\
\hline 2014 & $a$ & $b$ & $a b$ & $a b$ & c & $\mathrm{cd}$ & $d$ & e \\
\hline 2015 & $a$ & b & $b$ & b & $b$ & $\mathrm{~cd}$ & $\mathrm{~cd}$ & $\mathrm{e}$ \\
\hline
\end{tabular}

(2014), cocksfoot fertilised with mineral $\mathrm{N}$ presented better biomass accumulation results than if fertilised with digestate.

There were indications that cocksfoot swards fertilised with digestate performed better in the varying weather conditions experienced during the period 2010-2015 compared to swards fertilised with mineral $\mathrm{N}$ fertilisers. Especially in dry years like 2015, when the biomass yields of non-fertilised swards and those fertilised with mineral $\mathrm{N}$ were very low, 2.0-5.8 t dry matter (DM) $\mathrm{ha}^{-1}$, the swards fertilised with digestate produced from 4.1 to $8.4 \mathrm{t} \mathrm{DM} \mathrm{ha}^{-1}$.

\section{Biogas yield}

Average biomethane yields from the cocksfoot grass varied by up to $25 \%$ among scenarios (Table 5). The lowest methane yield of $317 \mathrm{l} \mathrm{kg}^{-1} \mathrm{DM}$ was found for SC1, where no fertiliser was applied. Significantly higher methane yields were obtained in SC2 and SC3, with 379 and $395 \mathrm{l} \mathrm{kg}^{-1}$ DM respectively, the highest yield being obtained from the highest mineral $\mathrm{N}$ application rate of $360 \mathrm{~kg} \mathrm{ha}^{-1}$ year $^{-1}$.

The opposite tendency was found in SC4-SC8, where the methane yield decreased with increasing $\mathrm{N}$ application rate as digestate. At $90 \mathrm{~kg} \mathrm{~N} \mathrm{ha}^{-1}$ year $^{-1}$ (SC4), the methane yield was $13.5 \%$ higher than at $450 \mathrm{~kg} \mathrm{~N} \mathrm{ha}^{-1}$ year $^{-1}$ (SC8). The methane yield decreased by about 3\% for each additional $90 \mathrm{~kg} \mathrm{~N} \mathrm{ha}^{-1}$ year $^{-1}$ applied.

For the same $\mathrm{N}$ application rates, the biogas yields were lower for biomass produced with digestate compared to mineral $\mathrm{N}$ fertiliser application (Table 4). Cocksfoot fertilised with mineral fertilisers produced
379-395 l methane $\mathrm{kg}^{-1} \mathrm{DM}$, while cocksfoot fertilised with digestate yielded 345-382 1 methane $\mathrm{kg}^{-1} \mathrm{DM}$. Only SC4 with addition of $90 \mathrm{~kg} \mathrm{~N} \mathrm{ha}^{-1}$ year $^{-1}$ gave a biomass yield in the same range as that of biomass fertilised with mineral $\mathrm{N}$ fertiliser.

The highest total biogas potential in a six-year period was from fields of swards fertilised with digestate (Fig. 3), due to higher yields outweighing the lower energy potential per biomass unit. Applying $180 \mathrm{~kg} \mathrm{~N} \mathrm{ha}^{-1}$ year $^{-1}$ as mineral fertiliser gave a similar biomethane yield per hectare compared to that from swards fertilised with the same rate of $\mathrm{N}$ applied as digestate, while an application rate of $360 \mathrm{~kg} \mathrm{~N} \mathrm{ha}^{-1}$ year $^{-1}$ as mineral fertiliser produced lower yields per hectare compared to the corresponding rate of applied $\mathrm{N}$ as digestate.

\section{Land area needed for the effective run of biogas plant}

The annual amount of biogas that could be obtained from the biomass produced from 1 ha was zero in the first year (2009) when the biomass was not harvested, and highest in 2010, when biomass yields were greatest in all scenarios. The biogas that could be obtained was lowest in 2015, when biomass yield was low, presumably due to droughts (Table 2) and aging of the sward. In that year, the unfertilised SC1, and SC2 and SC3 with application of mineral $\mathrm{N}$ fertiliser had very low grass yields of $1.5,2.4$ and $1.8 \mathrm{t} \mathrm{ha}^{-1}$ year ${ }^{-1}$, respectively, compared to 5.5, 9.2 and $9.3 \mathrm{t} \mathrm{ha}^{-1} \mathrm{yea}^{-1}$ in 2010 .

As a result, the land areas needed to obtain the required quantity of biomass to supply the modelled biogas plant in 2015 were high, 2394 ha in SC1, 1255 ha in

Table 5 Average methane yield of cocksfoot grass and standard deviation

\begin{tabular}{|c|c|c|c|c|c|c|c|c|}
\hline \multirow{2}{*}{$\begin{array}{l}\text { Fertiliser type } \\
\mathrm{N} \text { application rate }\left(\mathrm{kg} \mathrm{ha}^{-1}\right. \\
\left.\text { year }^{-1}\right)\end{array}$} & \multicolumn{3}{|c|}{ Mineral $\mathrm{N}$ fertiliser } & \multicolumn{5}{|l|}{ Digestate } \\
\hline & 0 & 180 & 360 & 90 & 180 & 270 & 360 & 450 \\
\hline Scenario & SC1 & SC2 & SC3 & SC4 & SC5 & SC6 & SC7 & SC8 \\
\hline Methane yield (I kg $\left.{ }^{-1} \mathrm{DM}\right)$ & $\begin{array}{l}317.4 \text { e } \pm \\
10.8\end{array}$ & $\begin{array}{l}378.5 b \pm \\
8.3\end{array}$ & $\begin{array}{l}395.3 \mathrm{a} \pm \\
8.5\end{array}$ & $\begin{array}{l}381.9 b \pm \\
8.9\end{array}$ & $\begin{array}{l}352.4 c \pm \\
10.2\end{array}$ & $\begin{array}{l}345.1 \mathrm{~cd} \pm \\
4.1\end{array}$ & $\begin{array}{l}342.8 \mathrm{~cd} \pm \\
7.9\end{array}$ & $\begin{array}{l}336.4 d \pm \\
5.3\end{array}$ \\
\hline
\end{tabular}


SC2 and 1602 ha in SC3 (Table 6). A reduction in biomass yield thus led to an increased need for grassland area to supply the modelled biogas plant and larger inputs from cultivation and fertiliser application to fulfil the complete biomass-biogas-biomass cycle.

Depending on the annual yields over the 6-year period, the average field area required to produce an equivalent amount of energy varied from 277 to 1143 ha for fields fertilised with digestate (SC4-SC8) and from 275 to 2394 ha for fields fertilised with mineral fertiliser (SC1SC3) (Table 6).

\section{Greenhouse gas emissions per area}

As the biomass yield varies between each scenario and year, corrections were made to calculate the area needed for the production of the same amount of biogas, with GHG emissions per area corrected accordingly.

In the establishment year, all scenarios had net GHG emissions because there was no yield of biomass for biogas production, with the indirect emissions from soils contributing significantly (Table 7). In the establishment year, SC3 emitted $1294 \mathrm{~kg} \mathrm{CO}_{2}$-eq ha ${ }^{-1}$ because the application of mineral $\mathrm{N}$ fertilisers was associated with indirect energy inputs mainly from the fossil fuels used in fertiliser production (Fig. 4). SC2 emitted $834 \mathrm{~kg} \mathrm{CO}_{2}$-eq $\mathrm{ha}^{-1}$. The GHG emissions from SC3, which were greater by $55 \%$ than those from SC2, were caused mainly by the greater application of mineral $\mathrm{N}$ fertiliser with no differences in the need for land area to produce the same amount of biogas. In the establishment year, emissions from SC2 and SC3, respectively, were lower than emissions from cocksfoot fertilised with corresponding amounts of $\mathrm{N}$ applied as digestate (SC5 and SC7). Otherwise, the emissions from SC4-SC8 depended on the rate of $\mathrm{N}$ applied as digestate. The application of digestate as fertiliser strongly contributed to the overall net GHG emissions, mainly because of higher $\mathrm{N}$ application rates as digestate-inducing higher $\mathrm{N}_{2} \mathrm{O}$ emissions from soil. SC4 emitted $1192 \mathrm{~kg} \mathrm{CO}_{2}$-eq ha ${ }^{-1}$ gradually increasing up to $4565 \mathrm{~kg} \mathrm{CO}_{2}$-eq ha ${ }^{-1}$ in SC8.
After correcting for different areas needed to produce the same amount of biogas in the years 2010-2015 (Table 7), the annual net GHG emission savings were largest in the first year of cocksfoot grass harvesting (2010), when biomass yields were also greatest in all scenarios, with net GHG emissions varying from $-2976 \mathrm{~kg}$ $\mathrm{CO}_{2}$-eq ha ${ }^{-1}$ in $\mathrm{SC} 1$ to $-5171 \mathrm{~kg} \mathrm{CO}_{2}$-eq ha ${ }^{-1}$ in SC3.

The total net GHG emissions in the 7-year period varied from 1897 to $-8540 \mathrm{~kg} \mathrm{CO}_{2}$-eq ha ${ }^{-1}$ depending on the type of fertiliser and the rate of application (Fig. 4). The total 7-year period showed net GHG emissions for SC3 and SC8 scenarios, and net emission reductions for $\mathrm{SC} 1, \mathrm{SC} 2$ and SC4-SC7. SC1 produced on average $2.7 \mathrm{t}$ $\mathrm{DM} \mathrm{ha}{ }^{-1}$ and thus had net GHG emission reductions of $-3760 \mathrm{~kg} \mathrm{CO}_{2}$-eq ha ${ }^{-1}$ which was similar to- $3598.6 \mathrm{~kg}$ $\mathrm{CO}_{2}$-eq $\mathrm{ha}^{-1}$ for $\mathrm{SC} 7$ which on average produced $7.7 \mathrm{t}$ $\mathrm{DM} \mathrm{ha}^{-1}$.

The high rate of digestate application caused higher indirect $\mathrm{N}_{2} \mathrm{O}$ emissions from soil in SC4-SC8, compared to the indirect $\mathrm{N}_{2} \mathrm{O}$ emissions from mineral fertiliser in SC2-SC3. However, SC3 still had overall net GHG emissions of $+1302 \mathrm{~kg} \mathrm{CO}_{2}$-eq ha ${ }^{-1}$ rather than an overall emission reduction. This was due to the low biomass yield and large area requirements, as well as indirect emissions from soil and fertiliser production (i.e. fossil fuel consumption for mineral fertiliser production). Over the 7-year period, SC8 emitted $1897 \mathrm{~kg} \mathrm{CO}_{2}$-eq ha ${ }^{-1}$, while SC3 emitted $1302 \mathrm{~kg} \mathrm{CO}_{2}$-eq ha ${ }^{-1}$, which in SC8 was caused mainly by indirect $\mathrm{N}_{2} \mathrm{O}$ emissions from application of high amounts of digestate, especially in 2009 with no energy production, and in SC3 due to indirect emissions from mineral fertiliser production and application. The indirect emissions from mineral fertiliser application were thus $22 \%$ of the total emissions in SC3, while they were $47 \%$ to $79 \%$ for SC4-SC8 where digestate was applied.

Biomass yields from scenarios involving digestate application (SC4-SC8) were more stable over time than yields from scenarios with application of mineral $\mathrm{N}$ fertiliser, and less land area was generally required to

Table 6 Land area (ha) required under different scenarios (SC) to produce the same quantity of energy (39,917 GJ) (see further details in the section "Ensuring comparability of the assessed scenarios")

\begin{tabular}{|c|c|c|c|c|c|c|c|c|}
\hline \multirow{2}{*}{$\begin{array}{l}\text { Fertiliser type } \\
\mathrm{N} \text { application rate }\left(\mathrm{kg} \mathrm{ha}^{-1} \text { year }^{-1}\right)\end{array}$} & \multicolumn{3}{|c|}{ Mineral $\mathrm{N}$ fertiliser } & \multicolumn{5}{|c|}{ Digestate } \\
\hline & $\overline{0}$ & 180 & 360 & 90 & 180 & 270 & 360 & 450 \\
\hline $\begin{array}{l}\text { Scenario } \\
\text { Year }\end{array}$ & $\mathrm{SC} 1$ & $\mathrm{SC} 2$ & $\mathrm{SC} 3$ & SC4 & $\mathrm{SC} 5$ & SC6 & SC7 & $\mathrm{SC} 8$ \\
\hline 2010 & 627 & 296 & 275 & 417 & 364 & 339 & 305 & 277 \\
\hline 2011 & 2144 & 510 & 623 & 698 & 454 & 391 & 350 & 434 \\
\hline 2012 & 2041 & 530 & 627 & 691 & 443 & 435 & 378 & 465 \\
\hline 2013 & 2270 & 974 & 1103 & 1098 & 975 & 810 & 698 & 644 \\
\hline 2014 & 1984 & 1083 & 1403 & 1143 & 772 & 639 & 583 & 475 \\
\hline 2015 & 2394 & 1255 & 1602 & 1105 & 829 & 674 & 616 & 499 \\
\hline
\end{tabular}




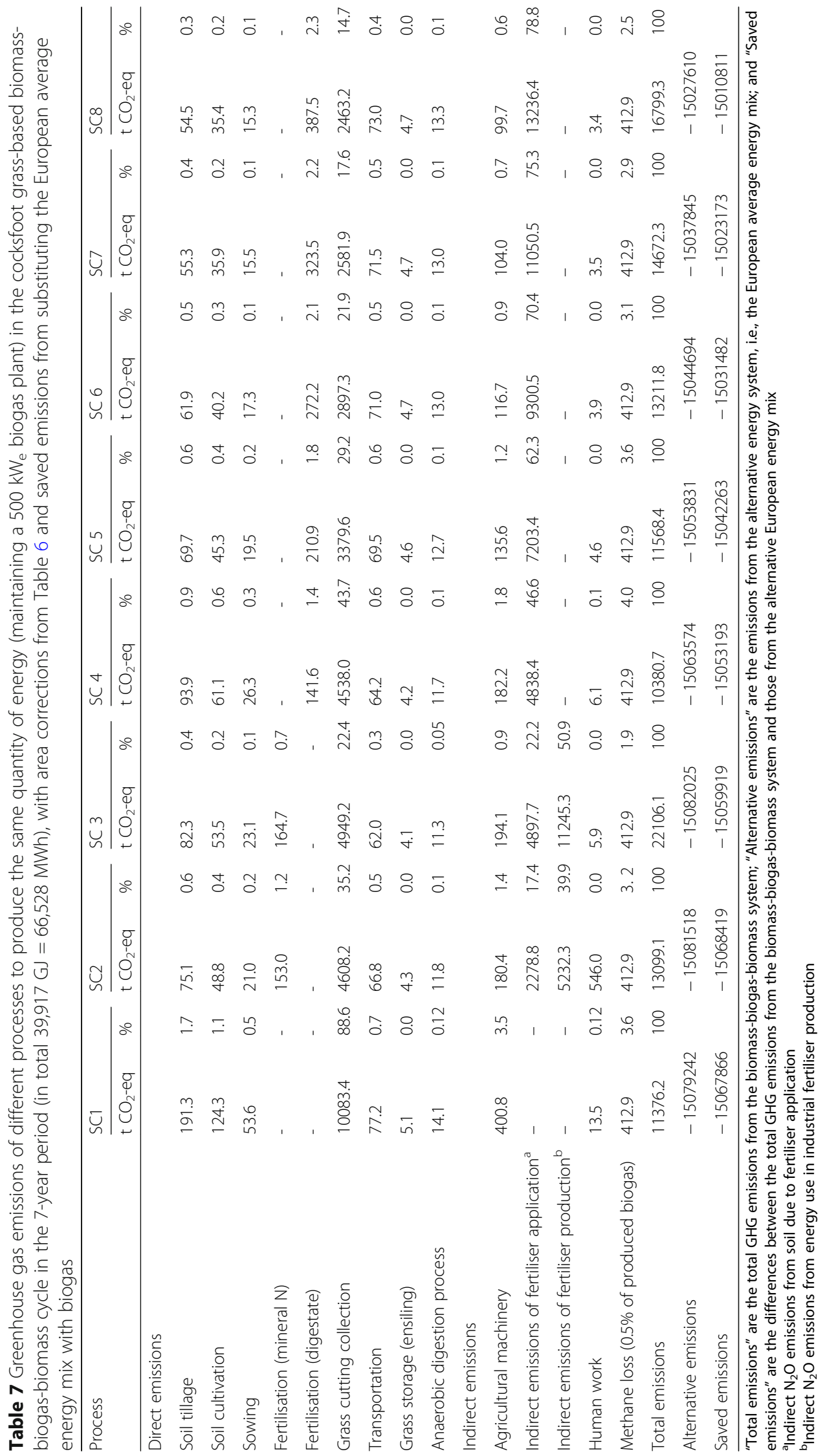




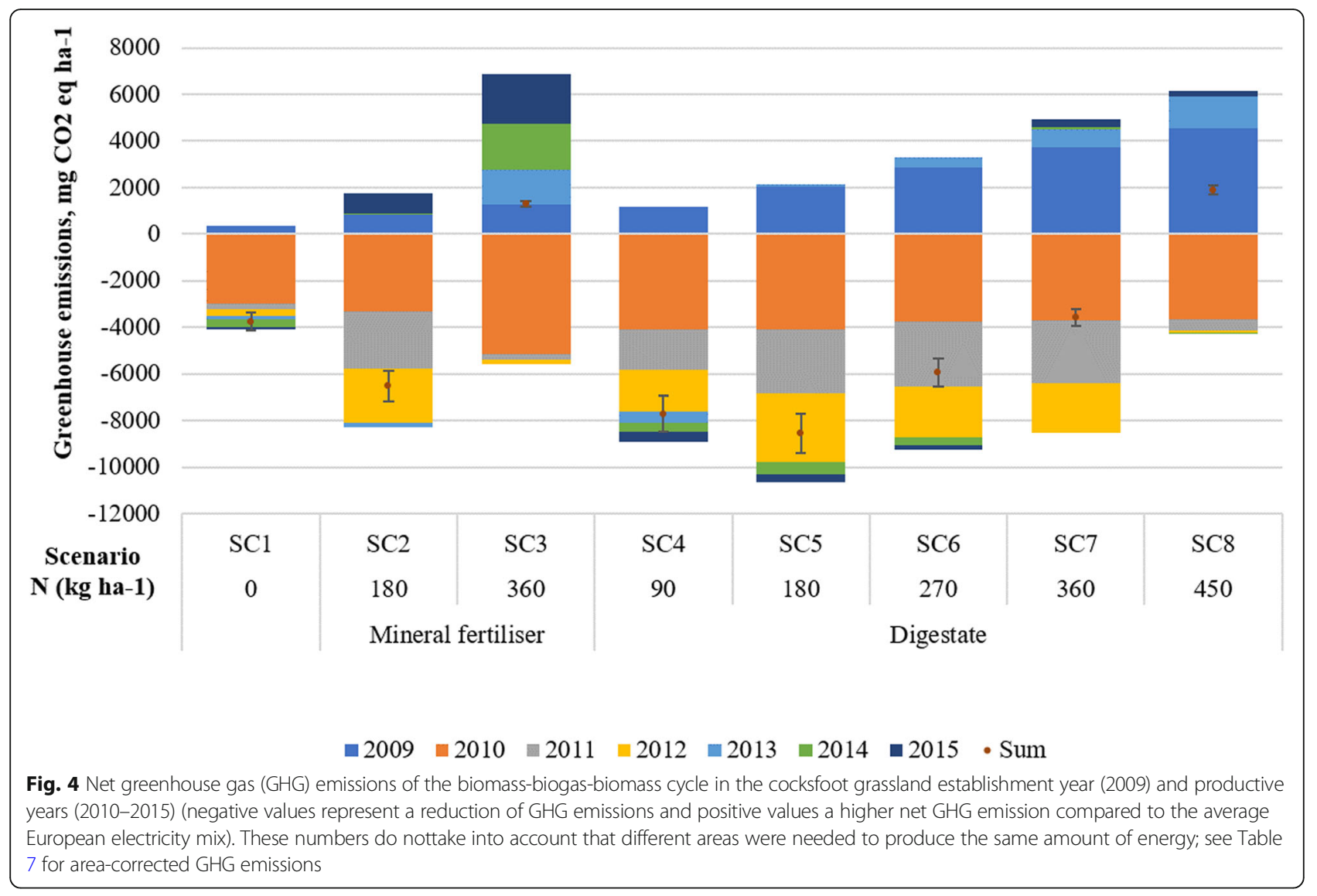

provide the feedstock to run a $500 \mathrm{~kW}_{\mathrm{e}}$ biogas power plant. The transportation contributes very little to the overall net emissions; applying digestate to the fields accounted for emissions of between $24 \mathrm{~kg} \mathrm{CO}_{2}$-eq ha ${ }^{-1}$ in $\mathrm{SC} 4$ and $120 \mathrm{~kg} \mathrm{CO}_{2}$-eq ha ${ }^{-1}$ in $\mathrm{SC} 8$ (obtained from a combination of results in Tables 6 and 7). Even transporting additional amounts of digestate to the fields did not outweigh the impact of mineral $\mathrm{N}$ fertilisation.

The application of digestate (SC4-SC7) as fertiliser thus strongly reduced the net GHG emissions by avoiding the fossil-fuel-based energy input associated with the use of mineral $\mathrm{N}$ fertilisers. The transporting of additional amounts of digestate to the fields only outweighed the impact of mineral $\mathrm{N}$ fertilisation at the highest amount of digestate application (SC8).

\section{Greenhouse gas emissions per energy unit}

The highest total GHG emissions per energy amount produced for each component in grass cultivation, based on the biogas plant functional unit of $500 \mathrm{~kW}_{\mathrm{e}}$, were found for SC3 (360 kg N ha ${ }^{-1}$ as mineral fertiliser) with 22,106 $\mathrm{t} \mathrm{CO}_{2}$-eq for the whole 7-year period (Table 7) during which a total of $39,917 \mathrm{GJ}\left(=66528 \mathrm{MWh}_{\mathrm{e}}\right)$ of energy would be produced.
Over all scenarios, individual year net GHG emissions ranged from a high of $0.868 \mathrm{~kg} \mathrm{CO}_{2}$-eq $\mathrm{kWh}_{\mathrm{e}}{ }^{-1}$ (SC3, $2015)$ to emission reductions of $0.467 \mathrm{~kg} \mathrm{CO}_{2}$-eq $\mathrm{kWh}_{\mathrm{e}}^{-1}(\mathrm{SC} 1,2010)$ (Table 8).

\section{Discussion}

The aim of this study was to quantify and compare the GHG emissions and emission savings from the cycle of biomass-biogas-biomass production system based on cocksfoot grass grown under different fertiliser application systems. As in other studies [42, 45], we found that the biogas yield mainly depend on the amount of biomass produced per hectare, with emissions and the energy benefits directly influenced by the biogas yield obtained per unit area. We also found that the biomass yield per hectare, as well as the associated direct and indirect emissions for the full cycle of the biomass-biogasbiomass system, depended significantly on the fertiliser type, the rate of $\mathrm{N}$ application and the interaction between the two. A balance thus needs to be made between biomass yield, associated GHG emissions per hectare, and the area needed to support a certain level of energy production. 
Table $8 \mathrm{GHG}$ emissions expressed as $\mathrm{CO}_{2}$-eq $\mathrm{kWh}_{\mathrm{e}}{ }^{-1}$ of electricity under different scenarios (SC)

\begin{tabular}{|c|c|c|c|c|c|c|c|c|}
\hline \multirow{2}{*}{$\begin{array}{l}\text { Fertiliser type } \\
\mathrm{N} \text { application rate }\left(\mathrm{kg} \mathrm{ha} \mathrm{a}^{-1} \mathrm{y}^{-1}\right)\end{array}$} & \multicolumn{3}{|c|}{ Mineral $\mathrm{N}$ fertiliser } & \multicolumn{5}{|c|}{ Digestive } \\
\hline & 0 & 180 & 360 & 90 & 180 & 270 & 360 & 450 \\
\hline $\begin{array}{l}\text { Scenario } \\
\text { Year }\end{array}$ & SC1 & $\mathrm{SC} 2$ & $\mathrm{SC} 3$ & $\mathrm{SC} 4$ & SC5 & SC6 & SC7 & SC8 \\
\hline 2010 & -0.467 & -0.246 & -0.355 & -0.426 & -0.372 & -0.317 & -0.282 & -0.253 \\
\hline 2011 & -0.125 & -0.314 & -0.034 & -0.304 & -0.314 & -0.273 & -0.234 & -0.053 \\
\hline 2012 & -0.148 & -0.303 & -0.031 & -0.307 & -0.322 & -0.235 & -0.204 & -0.013 \\
\hline 2013 & -0.097 & -0.047 & 0.408 & -0.129 & 0.023 & 0.087 & 0.138 & 0.216 \\
\hline 2014 & -0.161 & 0.016 & 0.684 & -0.110 & -0.109 & -0.060 & 0.015 & 0.000 \\
\hline 2015 & -0.069 & 0.269 & 0.868 & -0.126 & -0.072 & -0.030 & 0.050 & 0.031 \\
\hline Total 2010-2015 & -1.067 & -0.625 & 1.540 & -1.402 & -1.166 & -0.828 & -0.517 & -0.072 \\
\hline
\end{tabular}

\section{Net GHG emissions for mineral $\mathbf{N}$ fertiliser versus digestate}

Our results suggested that the trade-off can best be made by applying organic digestate as fertiliser in place of mineral $\mathrm{N}$ fertiliser, with an optimal rate of application of $180 \mathrm{~kg} \mathrm{~N}$ ha $^{-1}$ year $^{-1}$, for which net GHG emissions for the studied 7-year period ($8539.6 \mathrm{~kg} \mathrm{CO}_{2}$-eq $\mathrm{ha}^{-1}$ ) were lowest among all scenarios. Other research indicates that applying digestate instead of mineral fertiliser may reduce the energy input by up to three times for the same energy output [3]. We found that the biomass yield of cocksfoot grass fertilised with $\mathrm{N}$ at a rate of $180 \mathrm{~kg}$ $\mathrm{N} \mathrm{ha}{ }^{-1}$ year $^{-1}$ as digestate was similar to the yield when $\mathrm{N}$ was applied at the same rate as mineral fertiliser. The methane yields were only lower by $9 \%$ for the mineral fertiliser, but this difference was exacerbated by the indirect emissions of the $\mathrm{N}$ fertiliser production process, which requires 69.3 MJ of primary energy to produce $1 \mathrm{~kg}$ of ammonium nitrate fertiliser [47].

Other studies also find that organic fertilisers, such as biogas digestate, have the potential to improve the GHG performance of the whole biomass-biogas-biomass production cycle when it replaces mineral fertilisers, even if it must also be considered that it has different effects on biomass yield and quality [2, 45, 51, 52]. Zeshan [1] indicates that the effective soil application of digestate can avoid more than 93\% of GHG emissions compared to the storage of digestate.

Rösch et al. [45] found biogas yields in the range of 253 to $3941 \mathrm{~kg}^{-1} \mathrm{DM}$ from perennial grasses digested as mono-feedstock, with yield levels depending on the grass species, agricultural management and maturity stage at harvest and the number of harvests annually. They also found a tendency for biogas yield per unit DM to depend on whether mineral $\mathrm{N}$ fertiliser or organic digestate was being applied, with opposite trends for the rate of $\mathrm{N}$ application. As in this study, the biogas yield per DM increased with increasing rate of $\mathrm{N}$ application for mineral fertiliser, while it decreased for digestate.

\section{Soil and water}

There was no significant difference between biomass yields when applying $\mathrm{N}$ at a rate of 180 or $360 \mathrm{~kg} \mathrm{~N}$ $\mathrm{ha}^{-1}$ year $^{-1}$ (Table 4). Oppositely, applying more $\mathrm{N}$ with digestate continued to have a significant positive effect on biomass yields over the whole range of fertiliser application rates (Fig. 3, Table 4). It is desirable to increase biomass productivity generally, but especially for older grass cultures, as the yield tends to decrease with the number of years after initial establishment. Not only does digestate increase the amount of biogas production that can be supported by a given land area, but it also provides an important input of organic matter to the soil [29]. The increased organic matter in the soil may contribute to better plant nutrition, higher water-holding capacity and lower wind erosion. A modelling study for Salix and Miscanthus in Denmark showed that water availability is critical [53]. Applying digestate to grass instead of mineral fertiliser directly adds water as well as $\mathrm{N}$ and organic matter to the soil. We hypothesize that the digestate may have created more favourable conditions for grass growth especially during dry periods, compared to mineral fertiliser.

Applying as much as $450 \mathrm{~kg} \mathrm{~N}^{-1}$ year $^{-1}$ applied as digestate will likely cause some environmental problems, but more knowledge is needed to assess, for example, the amount of $\mathrm{N}$ leaching to waters from the soil. Georgiadis et al. [54] found that $\mathrm{N}$ leaching increases significantly with one-time additions of 240 and $360 \mathrm{~kg} \mathrm{~N} \mathrm{ha}^{-1}$ as mineral fertiliser in 2-year rotations, while the leaching of $\mathrm{N}$ was insignificant for applications of up to 120 $\mathrm{kg} \mathrm{N}^{-1}$ per rotation. However, when $240 \mathrm{~kg} \mathrm{~N}^{-1}$ per rotation was added with organic fertilisers, manure 
or sludge, they found significantly lower $\mathrm{N}$ leaching compared to additions of the same amount of $\mathrm{N}$ as mineral fertiliser.

\section{Comparing GHG emissions in the literature}

Other studies also address the life-cycle GHG emissions from biogas production systems with a focus on the influence of feedstock production. Bacenetti et al. [13] conducted an LCA evaluation of three biogas plants located in Italy, where they compared a biogas plant with electric power capacity of $520 \mathrm{~kW}_{\mathrm{e}}$ fed solely by maize silage to a reference system with electric energy generated from fossil fuels in Italy (with $541.7 \mathrm{~g} \mathrm{CO}_{2}$-eq $\mathrm{kWh}_{\mathrm{e}}{ }^{-1}$ emission). They found GHG emission savings of $0.514 \mathrm{~kg} \mathrm{CO}_{2}$-eq $\mathrm{kWh}_{\mathrm{e}}{ }^{-1}$, which agrees well with our findings of $0.426 \mathrm{~kg} \mathrm{CO}_{2}$-eq $\mathrm{kWh}_{\mathrm{e}}^{-1}$ for SC4 in year 2010. The scenario by Bacenetti et al. [14] is close to ours, because of mono-feedstock use and a biogas plant producing electricity, as well as the rate of $\mathrm{N}$ application being in the same range (346 $\mathrm{kg} \mathrm{N} \mathrm{ha}^{-1}$ year $^{-1}$ applied as organic digestate $\left(75 \mathrm{t} \mathrm{ha}^{-1}\right.$ year $\left.^{-1}\right)$.

Furthermore, Meyer et al. [19] analysed GHG emissions associated with a $500 \mathrm{~kW}_{\mathrm{e}}$ biogas power plant with different maize and grass cultivation scenarios for feedstock production. The feedstock was digested together with cattle manure, but GHG emissions due to digestion of the cattle manure were not taken into account. They found GHG emission savings ranging from 0.16 to 0.35 $\mathrm{kg} \mathrm{CO}$-eq $\mathrm{kWh}_{\mathrm{e}}{ }^{-1}$, which was lower than the corresponding values in this study (SC1 2010, Table 8), because the grasslands were cultivated with low rates of $\mathrm{N}$ fertiliser application (0 to $143 \mathrm{~kg} \mathrm{~N} \mathrm{ha}^{-1}$ year $^{-1}$ added as mineral fertiliser and digestate) and without taking into account the full cycle of perennial grass, including the establishment of the grass production system.

Rösch et al. [45] reported GHG emission savings of $4000 \mathrm{~kg} \mathrm{CO}_{2}$-eq $\mathrm{ha}^{-1}$ year $^{-1}$ using grass silage as monofeedstock in a $100 \mathrm{~kW}_{\mathrm{e}}$ biogas power plant, modelled with the Global Emission Model for Integrated Systems (GEMIS) software. These results were for grass cultivation without fertilisation, and had higher savings compared to SC1 in 2010, with GHG emission savings of $2976 \mathrm{~kg} \mathrm{CO}_{2}$-eq ha ${ }^{-1}$ year $^{-1}$. Our study showed that addition of fertiliser had a higher GHG mitigation potential.

\section{Sources of uncertainty}

There are various sources of uncertainty around our results. One source is that the methane yield would be lower in a continuous full-scale biogas plant compared to experimental batch tests. A standard method for the transfer of batch test to continuous working full-scale systems is not yet available, even if results by Holliger et al. [55] suggest a $10 \%$ higher methane potential is obtained from batch tests compared to the full-scale biogas plant yield.

Thinking of the biomass-biogas-biomass system as circular, it is also not consistent to use manure-based digestate as fertiliser, while the biogas production potential is measured based on grass mono-feedstocks. Digestate from grass-based mono-feedstock biogas production may have other qualities as fertiliser compared to digestate from co-digestion [56, 57]. However, the replacement of mineral with organic fertilisers is important in terms of environmental benefits, and the careful selection of co-substrates may even improve the results obtained in this study.

\section{Conclusions}

Cocksfoot grass fertilised with digestate is a promising feedstock for mono-feedstock biogas production. In the present study, biomass productivity increased with the rate of digestate applied. The biomass yield of cocksfoot swards fertilised with $180 \mathrm{~kg} \mathrm{~N} \mathrm{ha}^{-1}$ year $^{-1}$ as digestate was similar to that of swards fertilised with the same amount of $\mathrm{N}$ as mineral fertiliser. The overall net GHG emission savings increased when higher rates of $\mathrm{N}$ (up to $270 \mathrm{~kg} \mathrm{~N} \mathrm{ha}^{-1}$ year $^{-1}$ ) were applied as digestate, especially under dry weather conditions and as the sward grew old. Application of digestate as fertiliser in cultivation of cocksfoot grass offered overall a higher GHG emission mitigation potential compared to mineral fertiliser, when the same amount of energy is produced. The total reduction in GHG emissions was strongly influenced by the type of fertiliser, especially due to high indirect emissions associated with mineral fertiliser production. The results also suggest that biogas generation from low-yielding grasslands grown in intensive agricultural management systems is questionable in terms of the GHG emission mitigation potential. In these conditions, minor variations in technology can even lead to increased rather than decreased GHG emissions.

\section{Acknowledgment \\ Authors of the manuscript would like to thank Inge Stupak for her kind and professional help in editing the paper and all the suggestions for its improvement} and Jim Richardson for English language editing.

\section{Authors' contributions}

The paper is based on collective work, and all authors contributed to all parts. $\mathrm{VT}$ initiated the writing, prepared the introduction and the part of the Materials and Methods section which describes the field experiment. KV modelled scenarios and prepared the methodology of environmental impact assessment, and also carried out data analysis and the interpretation of the results. VP was responsible for the data analysis and worked on the literature review. KN supervised data collection from the biogas experiments and modelled the environmental indicators of grass biomass digestion. VZ planned and conducted the biogas production experiments, collected and presented data. ZK was responsible for the methodology of the field experiment and the research concept. All authors read and approved the final manuscript. 


\section{Authors' information}

Vita Tilvikiene is a senior researcher at the Lithuanian Research Centre for Agriculture and Forestry. She has a background in mechanical engineering and has a doctoral degree in Agronomy. Kestutis Venslauskas is a researcher and associate professor at the Vytautas Magnus University. He is responsible for biogas research at the University. Virmantas Povilaitis is a senior researcher at the Lithuanian Research Centre for Agriculture and Forestry. Kestutis Navickas is a professor at the Vytautas Magnus University. Vidmantas Zuperka is a lector at the Vytautas Magnus University. Zydre Kadziuliene is the head researcher at the Lithuanian Research Centre for Agriculture and Forestry.

\section{Funding}

This work was funded by the Ministry of Education, Science and Sports of Lithuania, and Ministry of Agriculture of Lithuania.

\section{Availability of data and materials}

This research relied on research results obtained during the experiment and in the literature.

\section{Ethics approval and consent to participate}

Not applicable.

\section{Consent for publication}

Not applicable.

\section{Competing interests}

The authors declare that they have no competing interests.

\section{Author details}

'Lithuanian Research Centre for Agriculture and Forestry, Instituto al. 1,

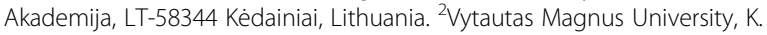
Donelaičio g. 58, LT-44248 Kaunas, Lithuania.

\section{Received: 22 October 2018 Accepted: 17 February 2020}

\section{Published online: 27 February 2020}

\section{References}

1. Zeshan VC (2014) Evaluation of anaerobic digestate for greenhouse gas emissions at various stages of its management. International Biodeterioration \& Biodegradation 95:167-175. https://doi.org/10.1016/J. IBIOD.2014.06.020

2. Berglund $M, B$ Börjesson $P$ (2006) Assessment of energy performance in the life-cycle of biogas production. Biomass and Bioenergy 30:254-266. https:// doi.org/10.1016/J.BIOMBIOE.2005.11.011

3. Dressler D, Loewen A, Nelles M (2012) Life cycle assessment of the supply and use of bioenergy: impact of regional factors on biogas production. The International Journal of Life Cycle Assess 17:1104-1115. https://doi.org/10. 1007/s11367-012-0424-9

4. Lijó L, González-García S, Bacenetti J, Fiala M, Feijoo G, Lema JM, Moreira MT (2014) Life Cycle Assessment of electricity production in Italy from anaerobic co-digestion of pig slurry and energy crops. Renew Energy 68: 625-635. https://doi.org/10.1016/J.RENENE.2014.03.005

5. Jury C, Benetto E, Koster D, Schmitt B, Welfring J (2010) Life cycle assessment of biogas production by monofermentation of energy crops and injection into the natural gas grid. Biomass and Bioenergy 34:54-66. https://doi.org/10.1016/J.BIOMBIOE.2009.09.011

6. Ozturk M, Saba N, Altay V, Iqbal R, Hakeem KR, Jawaid M, Ibrahim FH (2017) Biomass and bioenergy: An overview of the development potential in Turkey and Malaysia. Renewable and Sustainable Energy Reviews 79:12851302. https://doi.org/10.1016/j.rser.2017.05.111

7. Manolis EN, Zagas TD, Poravou CA, Zagas DT (2016) Biomass assessment for sustainable bioenergy utilization in a Mediterranean forest ecosystem in northwest Greece. Ecological Engineering 91:537-544. https://doi.org/10. 1016/j.ecoleng.2016.02.041

8. Mola-Yudego B, Arevalo J, Díaz-YO DI, Haapala A, ACF F, Selkimaki M, Valbuena R (2017) Wood biomass potentials for energy in northern Europe: Forest or plantations? Biomass and Bioenergy 106:95-103. https://doi.org/ 10.1016/j.biombioe.2017.08.021

9. Lattimore B, Smith CT, Titus BD, Stupak I, Egnell G (2009) Environmental factors in woodfuel production: Opportunities, risks, and criteria and indicators for sustainable practices. Biomass and Bioenergy 33:1321-1342. https://doi.org/10.1016/J.BIOMBIOE.2009.06.005

10. Pahla G, Mamvura TA, Ntuli F, Muzenda E (2017) Energy densification of animal waste lignocellulose biomass and raw biomass. South African Journal of Chemical Engineering 24:168-175. https://doi.org/10.1016/j.sajce. 2017.10.004

11. Lozano FJ, Lozano R (2018) Assessing the potential sustainability benefits of agricultural residues: Biomass conversion to syngas for energy generation or to chemicals production. Journal of Cleaner Production 172:4162-4169. https://doi.org/10.1016/j.jclepro.2017.01.037

12. Digman MF, Shinners KJ, Casler MD, Dien BS, Hafield RD, Jung HJG, Muck RE, Weimer PJ (2010) Optimizing on-farm pretreatment of perennial grasses for fuel ethanol production. Bioresour Technol 101:5305-5314. https://doi. org/10.1016/j.biortech.2010.02.014

13. Bacenetti J, Negri M, Fiala M, González-García S (2013) Anaerobic digestion of different feedstocks: Impact on energetic and environmental balances of biogas process. Science of The Total Environ 463-464:541-551. https://doi. org/10.1016/j.scitotenv.2013.06.058

14. Amon T, Amon T, Kryvoruchko V, Amon B (2004) Methane production from maize, grassland and animal manures through anaerobic digestion. Organic Waste treatments: Safety Implications. doi: 10.1.1.626.612

15. Haberl H, Erb K-H, Krausmann F, Bondeau A, Lauk C, Muller C, Plutzar C, Steinberger JK (2011) Global bioenergy potentials from agricultural land in 2050: sensitivity to climate change, diets and yields. Biomass and Bioenergy 35:4753-4769. https://doi.org/10.1016/j.biombioe.2011.04.035

16. Ramcilovic-Suominen S, Pülzl H (2018) Sustainable development-a 'selling point' of the emerging EU bioeconomy policy framework. Jornal of Cleaner Production 172:4170-4180. https://doi.org/10.1016/j.jclepro.2016.12.157

17. Canadell JG, Schulze ED (2014) Global potential of biospheric carbon management for climate mitigation. Nature Communications 5:5282. https://doi.org/10.1038/ncomms6282

18. Angeli JRB, Morales A, Lefloc'h T, Lakel A, Andres Y (2018) Anaerobic digestion and integration at urban scale: feedback and comparative case study. Energy, Sustainability and Society 8:29. https://doi.org/10.1186/ s13705-018-0170-3

19. Meyer AKP, Ehimen EA, Holm-Nielsen JB (2018) Future European biogas: animal manure, straw and grass potentials for a sustainable European biogas production. Biomass and Bioenergy 111:154-164. https://doi.org/10. 1016/J.BIOMBIOE.2017.05.013

20. Bedoic R, CuCek BL, Cosic B, Krajnc D, Smoljanic G, Kiravanja Z, Ljubas D, Pukšec T, Duic N (2018) Green biomass to biogas e A study on anaerobic digestion of residue grass. Journal of Cleaner Production 213:700-709. https://doi.org/10.1016/j.jclepro.2018.12.224

21. Tilvikiene V, Kadziuliene Z, Dabkevicius Z, Venslauskas K, Navickas K (2016) Feasibility of tall fescue, cocksfoot and reed canary grass for anaerobic digestion: analysis of productivity and energy potential. Industrial Crops and Products 84:87-96. https://doi.org/10.1016/j.indcrop.2016.01.033

22. Lemežiene N, Kanapeckas J, Tarakanovas P, Nekrošas S (2004) Analysis of dry matter yield structure of forage grasses. Plant, Soil Environ 50:277-282. doi. org/10.17221/4033-PSE

23. Apie Natura 2000 - Natura 2000. http://www.natura2000info.lt/lt/apienatura-2000.html.

24. Johansen A, Nielsen HB, Hansen CM, Adreasen C, Carlsgart J, Hauggard-Nielsen H, Roepstorff A (2013) Survival of weed seeds and animal parasites as affected by anaerobic digestion at meso- and thermophilic conditions. Waste Management 33:807-812. https://doi.org/10.1016/JWASMAN.2012.11.001

25. Dumontet S, Dinel H, Baloda SB (1999) Pathogen reduction in sewage sludge by composting and other biological treatments: a review. Biological Agriculture\&Horticticulture 16:409-430. https://doi.org/10.1080/01448765. 1999.9755243

26. Martens W, Böhm R (2009) Overview of the ability of different treatment methods for liquid and solid manure to inactivate pathogens. Bioresource Technology 100:5374-5378. https://doi.org/10.1016/J.BIORTECH.2009.01.014

27. Walsh JJ, Jones DL, Edwards-Jones G, Williams AP (2012) Replacing inorganic fertilizer with anaerobic digestate may maintain agricultural productivity at less environmental cost. Journal of Plant Nutrition and Soil Science 175:840-845. https://doi.org/10.1002/jpln.201200214

28. Dahlin AS, Ramezanian A, Campbell CD, Hillier S, Oborn I (2015) Waste recovered by-products can increase growth of grass-clover mixtures in low fertility soils and alter botanical and mineral nutrient composition. Annals Applied Biology 166:105-117. https://doi.org/10.1111/aab.12168 
29. Möller K, Müller T (2012) Effects of anaerobic digestion on digestate nutrient availability and crop growth: A review. Engineering in Life Sciences 12:242257. https://doi.org/10.1002/elsc.201100085

30. Butkutè B, Lemežienè N, Kanapeckas J, Navickas K, Dabkevičius Z, Venslauskas K (2014) Cocksfoot, tall fescue and reed canary grass: Dry matter yield, chemica composition and biomass convertibility to methane. Biomass and Bioenergy 66:1-11. https://doi.org/10.1016/j.biombioe.2014.03.014

31. Tilvikiene V, Kadziuliene Ž, Dabkevicius Z, Šarūnaitè L, Šlepetys J, Pocienè L, Šlepetienè A, Cecevičienè J (2014) The yield and variation of chemical composition of cocksfoot biomass after five years of digestate application. Grassland Science in Europe 19:50

32. Tilvikiene V, Venslauskas K, Navickas K, Župerka V, Dabkevičius Z, Kadžiuliené Ž (2012) The biomass and biogas productivity of perennial grasses. Zemdirbyste 99:17-22

33. Nekrošius A, Navickas K, Venslauskas K, Kadžiulienė Ž, Tilvikienè V (2014) Assessment of energy biomass potential and greenhouse gas emissions from biogas production from perennial grasses. Zemdirbyste 101:217-278. doi: 10.13080/z-a.2014.101.035

34. Tilvikienè V, Šlepetienè A, Kadžiulienè Ž (2017) Effects of 5 years of digestate application on biomass production and quality of cocksfoot ( Dactylis glomerata L.). Grass and Forage Science 73:206-217. https://doi.org/10.1111/ gfs. 12306

35. Fao World reference base for soil resources (2014) International soil classification system for naming soils and creating legends for soil maps Update 2015 WORLD SOIL RESOURCES REPORTS.

36. Clewer AG, Scarisbrick DH (2001) Practical statistics and experimental design for plant and crop science. West Sussex, England, p 344

37. Hong J, Hong J, Otaki M, Jolliet O (2009) Environmental and economic life cycle assessment for sewage sludge treatment processes in Japan. Waste Management 29:696-703. doi: 10.1016jwasman.2008.03.026

38. Impact 2002+: GaBi Software. http://www.gabi-software.com/international/ support/gabi/gabi-lcia-documentation/impact-2002/. Accessed 21 Oct 2018

39. Elsevier Science (Firm) T, McKenna R, Fichtner W (2014) Energy conversion and management, Pergamon

40. Salter AM, Holiday L, Banks CJ, Chessire M, Mulliner R (2005) Plant biomass as an energy efficient feedstock in the production of renewable energy.

41. Yadvika S, Sreekrishnan TR, Kohli S, Rana V (2004) Enhancement of biogas production from solid substrates using different techniques--a review. Bioresource Technology 95:1-10. https://doi.org/10.1016/j.biortech.2004.02.010

42. Gissén C, Prade T, Kreuger E, Nges IA, Rosenqvist H, Svensson SE, Lantz M, Mattsson JE, Borjesson P, Bjornsson L (2014) Comparing energy crops for biogas production-yields, energy input and costs in cultivation using digestate and mineral fertilisation. Biomass and Bioenergy 64:199-210. https://doi.org/10.1016/J.BIOMBIOE.2014.03.061

43. Nekrošius A, Navickas K, Venslauskas K, Kadžiulienè Ž, Tilvikienė V (2014) Assessment of energy biomass potential and greenhouse gas emissions from biogas production from perennial grasses. Zemdirbyste-Agriculture 101:271-278. https://doi.org/10.13080/z-a.2014.101.035

44. UCTE | Resources | Data Portal | Statistics | exchange data. https://www.ucte org/resources/dataportal/statistics/exchange/.

45. Møller J, Boldrin A, Christensen TH (2009) Anaerobic digestion and digestate use: accounting of greenhouse gases and global warming contribution. Waste Management\&Reasearch 27:813-824. https://doi.org/10.1177/ $0734242 \times 09344876$

46. Harty MA, Forrestal PJ, Watson CJ, McGeough KL, Carolan R, Elliot C, Krol D, Laughlin RJ, Richards KG, Lanigan GJ (2016) Reducing nitrous oxide emissions by changing $\mathrm{N}$ fertiliser use from calcium ammonium nitrate (CAN) to urea based formulations. Science of The Total Environment 563564:576-586. https://doi.org/10.1016/j.scitotenv.2016.04.120

47. Wernet G, Bauer C, Steubing B, Reinhard J, Moreno-Ruiz E, Weidema B (2016) The ecoinvent database version 3 (part I): overview and methodology. The International Journal of Life Cycle Assessment 21:12181230. https://doi.org/10.1007/s11367-016-1087-8

48. Rugani B, Panasiuk D, Benetto E (2012) An input-output based framework to evaluate human labour in life cycle assessment. The International Journal of Life Cycle Assessment 17:795-812. https://doi.org/10.1007/s11367-012-0403-1

49. Bird N, Cowie A, Cherubini F, Cherubini G, Jungmeier G (2011) IEA bioenergy using a life cycle assessment approach to estimate the net greenhouse gas emissions of bioenergy. Report:1-20

50. Rösch C, Skarka J, Raab K, Stelzer V (2009) Energy production from grassland-assessing the sustainability of different process chains under
German conditions. Biomass and Bioenergy 33:689-700. https://doi.org/10. 1016/J.BIOMBIOE.2008.10.008

51. De Klein CAM, Barton L, Sherlock RR, Li Z, Littlejohn RP (2003) Estimating a nitrous oxide emission factor for animal urine from some New Zealand pastoral soils. Austalian Journal of Soil Research 41:381-399. https://doi.org/ 10.1071/SR02128

52. Larsen S, Jaiswal D, Bentsen NS, Wang D, Long SP (2016) Comparing predicted yield and yield stability of willow and Miscanthus across Denmark. Global Change Biology Bioenergy 8:1061-1070. https://doi.org/10. $1111 /$ gcbb. 12318

53. Georgiadis P, Sevel L, Raulund-Rasmussen K, Stupak I (2017) Fertilization of Willow coppice over three consecutive 2-year rotations-effects on biomass production, soil nutrients and water. BioEnergy Research 10:728-739. https://doi.org/10.1007/s12155-017-9834-7

54. Holliger C, Fruteau de Laclos H, Hack G (2017) Methane production of fullscale anaerobic digestion plants calculated from substrate's biomethane potentials compares well with the one measured on-site. Frontiers in Energy Research. https://doi.org/10.3389/fenrg.2017.00012

55. Alburquerque JA, de la Fuente C, Campoy M, Carrasco L, Najera I, Baixauli C, Caravaca F, Roldan A, Cegarra J, Benal MP (2012) Agricultural use of digestate for horticultural crop production and improvement of soil properties. European Journal of Agronomy 43:119-128. https://doi.org/10. 1016/j.eja.2012.06.001

56. Barbosa DBP, Nabel M, Jablonowski ND (2014) Biogas-digestate as nutrient source for biomass production of Sida hermaphrodita, Zea mays L. and Medicago sativa L. Energy Procedia 59:120-126. https://doi.org/10.1016/j. egypro.2014.10.357

57. Cavalli D, Cabassi G, Borrelli L, Geromel G, Bechini L, Degano L, Gallina PM (2015) Nitrogen fertilizer replacement value of undigested liquid cattle manure and digestates. European Journal of Agronomy 73:34-41. https:// doi.org/10.1016/j.eja.2015.10.007

\section{Publisher's Note}

Springer Nature remains neutral with regard to jurisdictional claims in published maps and institutional affiliations.
Ready to submit your research? Choose BMC and benefit from:

- fast, convenient online submission

- thorough peer review by experienced researchers in your field

- rapid publication on acceptance

- support for research data, including large and complex data types

- gold Open Access which fosters wider collaboration and increased citations

- maximum visibility for your research: over $100 \mathrm{M}$ website views per year

At $\mathrm{BMC}$, research is always in progress.

Learn more biomedcentral.com/submissions 